\title{
The Impact of China's Accession to the WTO on Tax and Customs Revenues
}

\author{
Husam Yaseen Mohsin ${ }^{1,2}$ \\ ${ }^{1}$ School of management, Huazhong University of Science \& Technology, Wuhan, China \\ ${ }^{2}$ Foreign Economic Relations Department, Ministry of Trade, Baghdad, Iraq \\ Correspondence: Husam Yaseen Mohsin, School of management, Huazhong University of Science \& \\ Technology, Wuhan, China. E-mail: m.hussam@yahoo.com
}

Received: September 11, 2015

Accepted: December 29, 2015

Online Published: January 25, 2016

doi:10.5539/ijef.v8n2p81

URL: http://dx.doi.org/10.5539/ijef.v8n2p81

\begin{abstract}
The paper identifies the importance of the Chinese accession to WTO and provides the basic information towards the import and export regulations after it. It also gives the historical background to the gradual and continuous liberalization of the foreign trade in China, explaining that it was a long and challenging process for the Chinese economic system. With the accession to WTO, China was obliged to reduce its import tariffs and lose the considerable sums of tariff revenues, which it was supposed to compensate with the help of the other regulations. The paper considers the effectiveness of such regulations and offers the alternative ways of compensation that appear to be more effective in this regard. In addition, the paper also gives the contemporary overview of the tariff reduction policy of China, analyzing the advantages and disadvantages of the last. It concludes that the Chinese government has to face a great set of challenges and undergo a great variety of political and economic reforms to effectively compensate such losses.
\end{abstract}

Keywords: Tariffs, World Trade Organization (WTO), tax, customs, Nontariff Barrier (NTB)

\section{Introduction}

Discussing the impact of accession of China to The World Trade Organization (WTO), it should be noted first that it was one of the few countries that were allowed to re-enter the membership in the organization. Just like the majority of the world organizations, WTO rejects any probability for the country to have a readmission automatically. As the WTO's predecessor lost China as a member in 1949 after the Communist revolution, the last had been waiting for another 15 years to become a member once again. China reapplied in the 1980 and it was granted the membership on the $11^{\text {th }}$ of December 2001 (World Trade Organization, 2011).

Certainly, the price of re-admission was more than significant, as well. Chinese government had to soften approximately 7,000 of their trade barriers, including quotas and tariffs. The native and foreign experts and critics were afraid that the accession would result in the bankruptcy of the farmers and re-shape the state-owned businesses completely due to the growing foreign competition. Nevertheless, it should be admitted that China has achieved one of the best results in their economy with the accession, as its GDP has almost quadrupled; moreover, its amount of exports had grown on almost 500\% (Hong, 2013).

In addition, the foreign businesses and investors have achieved great results, as well. For example, the American FDI's (foreign direct investments) had the returns of approximately 9,7\% worldwide, while the Chinese returns amounted for almost $13,5 \%$ at the same time. This could be explained by the simple fact that the Chinese tariff policy offers one of the lowest tariffs on average even when compared to the same of India or Brazil. The fact is that China imposes the tariffs almost equally to the recommendations of WTO tariffs; therefore, China has no possibility to raise their tariffs (Hong, 2013).

Nevertheless, despite the fact that the biggest trading partner of China is America, the attitude of the last has drastically changed to negative, as one of the latest polls shows that more than $60 \%$ of Americans identified the Chinese growth as a threat to American and only $15 \%$ expressed the positive opinion towards the Chinese development. Such frustration can partially be explained by the contemporary success of the Chinese economic system and its functioning according to the recommendations of WTO. Needless to state that the Chinese accession to WTO has become the great stimulation for the Chinese economic development; thus, China has 
become one of the greatest competitors on the foreign markets (The Economist, 2011).

Furthermore, the success of the Chinese economic system has also become a result of the number of changes in taxation and tariff systems of China. Therefore, the current project will focus on the tax and tariff systems before and after the Chinese accession to WTO comparing both at the same time. The paper will also offer the graphic material as the illustration for the changes in these systems. Moreover, it will analyze the positive and negative results and consequences of the accession to WTO, as well. The members of WTO consider the Chinese economic system and its way to administer their policies somehow ugly; however, the economists and investors undoubtedly state that China has designed one of the most effective ways to develop a strong and competitive economic system (Yijnling, n.d.).

\section{The Historical Process of Tariff Policies of China before the Accession to WTO}

Starting from 1979, the foreign trade system of China has been undergoing the significant changes; moreover, it goes without saying that it keeps on changing even today. The historical analysis of the changes in the foreign trade system of China will become with the launch of the contract management responsibility system in 1988, which was obligatory to follow for all the foreign trade companies operating in China. In 1991, there was a considerable abolishment of the subsidizing the Chinese exports; therefore, the foreign trade companies were made the only ones responsible for the effectiveness of their foreign trade and their losses and profits, as a result. In 1994 there was established a management "remibi" or RMB system of demand and supply of the Chinese foreign market along with the RMB's market rate and official rate merging (Yijnling, n.d.).

Thus, starting from 1996, the RMB received the effective conversion for the current account. In addition, in 1994, the guiding plans system was launched. It proclaimed the mandatory establishment and following of the plans regarding the amounts of export and import with the expenditures on import on the foreign market and the respective revenues from the exporting activity. Also, that year the unified system of tax compensation was introduced and gradually implemented. Such system also introduced the principles of openness, fairness and efficiency; therefore, it has offered the attractive conditions for the effective functioning of the auctions, public bidding with the corresponding standardized implementation of the tariff and non-tariff barriers towards the foreign trade. Certainly, the respective actions have been implemented to continuously stimulate the competitiveness on the market and in order to deregulate the exporters (Yijnling, n.d.).

In accordance with the principles of efficiency, fairness and openness, favorable conditions were created for public bidding, auction and standardized allocation for the quotas on import and export commodities. Actions have been taken to deregulate export businesses gradually to increase competitiveness.

The governmental organizations regulating the foreign trade in China have also developed a great variety of standardized documents regulating the import, exports with the respective regulations of the tariff and non-tariff barriers towards the foreign trade for the domestic market protection. However, despite this great list of the documents there was still too much to adjust and to implement for China to have a transparent and efficient system of foreign trade and its management. Moreover, such system creates a number of challenges for the establishment of the effective internal competition that would be potentially distorted by the importers with the increasing percentage of their items on the Chinese markets; furthermore, in regards of the FDI's, the Chinese financial and industrial markets remained unclear at those times (Yijnling, n.d.).

In its attempt to provide a competitive and liberalized economy, China has also been making successful attempts in lowering the import tariffs; for example, in 1991, the taxes on 43 items were reduced. In April 1992, there was an import tariff being imposed on the chemical fiber, electronics and machinery, while one the $1^{\text {st }}$ of the October that year the tariffs were reduced on another 225 items due to a new catalogue system of the commodities. By the end of 1992, the total number of 3371 items was subject to lowering the import tariffs on them. This number kept on increasing, on a great diversity of the commodities; moreover, starting from October 1997, the tariff rate achieved the mark of $17 \%$. Such tariff affected a number of more than 5000 commodities subject to the Chinese import (Fanchang, 1996).

Thus, as a result of these changes, the management system of the Chinese foreign trade has gone through a considerable set of reforms. Additionally to the aforementioned measures of the liberalization of its foreign trade, China also wanted to increase transparency of its economic system; thus, the government has introduced a set of documents that regulated the barriers towards trade and therefore regulated the activity of the exporters and importers, also introducing a great number of the new businesses ready to start their foreign trade activity.

As for the brief history of Chinese tariff changes, it should be mentioned that the date of 1951 is the most important in the history of China's foreign trade. Then, the first Customs with the respective schedules of 
Export/Import Tariffs were introduced. The arithmetic average of the rate of tariff was approximately 52.9\%, being calculated from $92.3 \%$ for the products of agricultural industry and $47.7 \%$ for the industrial items. The fundamental ideology of the first examples of such schedules was to "guarantee domestic production and protect domestic industries from competition from foreign goods." (State Statistical Bureau, 1997)

In 1985, the second edition of the Schedule was publicly launched with the tariff rates for intermediate goods of $27.2 \%$, for capital goods $-31.2 \%$ and for the consumer goods-62.6\%. Thus, the average tariff rate was approximately $38 \%$ (agricultural products $-43.6 \%$ and industrial products amounted for $36.9 \%$ ). Till 1992, the rates of tariffs were amended gradually but with small steps, as approximately 83 commodities were reduced with the 140 of another ones being enlarged. In 1992, there was an adoption of the third edition of the Schedule that introduced the significant changes in the categories of the items; although, it changed the tariff rates only slightly. At those times, the average tariff rate amounted for approximately $42.5 \%$ (State Statistical Bureau, 1997). Nevertheless, in the period of 1992-1996, there were four grate tariff decreases in China. Moreover, in 1996, there was the greatest reductions of the tariff rates since the foundation of the People's Republic of China. More than $70 \%$ of the taxable products were affected by those reductions, which included more than 4900 commodities (Chao Rihui, 1996). Furthermore, that year the new tariff rates were introduced, with a simple and weighted average figures for the tariff rates being $23 \%$ and $19 \%$ respectively. Further, China has completed a considerable set of the reductions in order to achieve the plan established by the government of those years, as the main goal of that plan was to achieve the tariff rate below 15\%. Afterwards, China has accessed to WTO and further changes in its foreign trade policies have occurred (Kim, 1997).

\section{The Process of Tariff Reforms in China after the Accession to WTO}

First of all, the project needs to mention the exact figures and show the main trend for the dynamics of the tariffs revenues before and after the accession to WTO. Thus, the following table and graphic show that 2000 and 2001 were the years of the highest shares of the tariff revenues in Chinese GDP; however, it is clearly visible that this share keeps on decreasing from year to year and according to the data for 2013, it shown one of the lowest incomes from tariff and customs revenues (Stats.gov.cn, 2015). The years with lower incomes were only before the accession due to a variety reasons and reforms mentioned above. The project will also discuss the ways on how the Chinese government compensates these losses and effectiveness of these measures, as well.

Table 1. Tariff revenues' share in the GDP of China, 1991-2013 (Stats.gov.cn, 2015)

\begin{tabular}{lccc}
\hline Date & GDP, 100 mln. Yuan & Tariffs, $100 \mathrm{mln}$. Yuan & Tariffs' incomes in GDP \\
\hline 1991 & 21781.5 & 187.28 & $0.86 \%$ \\
1992 & 26923.5 & 212.75 & $0.79 \%$ \\
1993 & 35333.9 & 256.47 & $0.73 \%$ \\
1994 & 48197.9 & 272.68 & $0.57 \%$ \\
1995 & 60793.7 & 291.83 & $0.48 \%$ \\
1996 & 71176.6 & 301.84 & $0.42 \%$ \\
1997 & 78973.0 & 319.49 & $0.40 \%$ \\
1998 & 84402.3 & 313.04 & $0.37 \%$ \\
1999 & 89677.1 & 562.23 & $0.63 \%$ \\
2000 & 99214.6 & 750.48 & $0.76 \%$ \\
2001 & 109655.2 & 840.52 & $0.77 \%$ \\
2002 & 120332.7 & 704.27 & $0.59 \%$ \\
2003 & 135822.8 & 923.13 & $0.68 \%$ \\
2004 & 159878.3 & 1043.77 & $0.65 \%$ \\
2005 & 184937.4 & 1066.17 & $0.58 \%$ \\
2006 & 216314.4 & 1141.78 & $0.53 \%$ \\
2007 & 265810.3 & 1432.57 & $0.54 \%$ \\
2008 & 314045.4 & 1769.95 & $0.56 \%$ \\
2009 & 340902.8 & 1483.81 & $0.44 \%$ \\
2010 & 401512.8 & 2027.83 & $0.51 \%$ \\
2011 & 473104.0 & 2559.12 & $0.54 \%$ \\
2012 & 519470.1 & 2783.93 & $0.54 \%$ \\
2013 & 568845.2 & 2630.61 & $0.46 \%$ \\
\hline
\end{tabular}




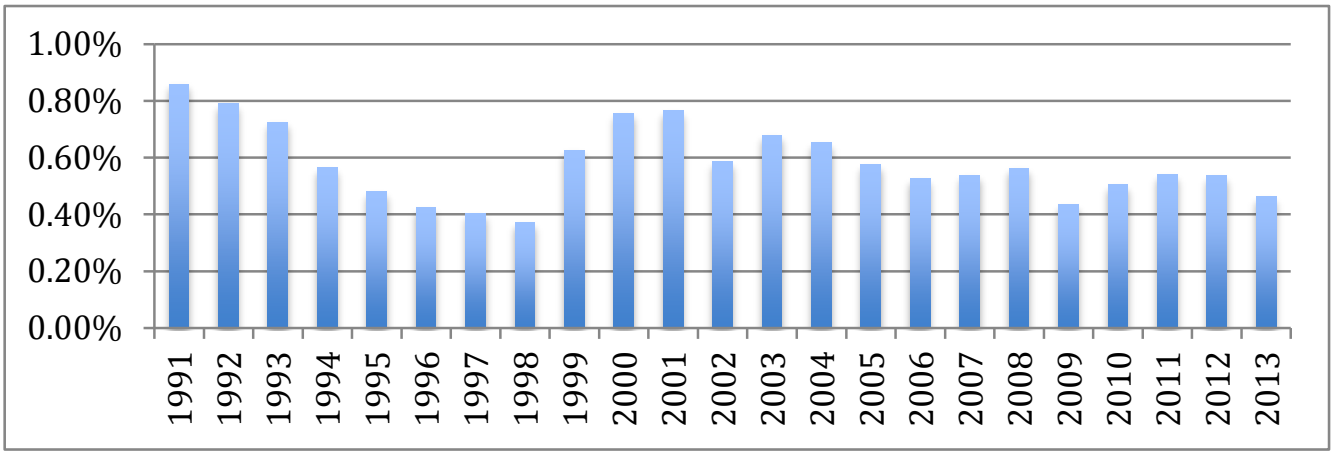

Figure 1. Tariff revenues' share in the GDP of China, 1991-2013 (Stats.gov.cn, 2015)

It should also be reminded that China has made a considerable breakthrough in reducing the nontariff barriers coverage, abolishing the foreign trade confines and reducing tariffs, as well. This substantial progress can be dated within the period of 1990s when they have nullified the exchange rate regime trade distortions.

Scholars estimate that the amount of tariff items that appear to be the subjects to quotas decreased from 1247 in 1992 to 261 in 1999. Moreover, by 2001, it is reported that 257 tariff items were covered by the mixture of quotas and licenses, while 47 lines were covered solely by licenses. In addition, 245 lines appeared to be the subject to designated trading, while the number of lines subject to state trading was 84 . Additional 120 tariff lines were covered by the registration requirements, including the tendering ones, mostly for electrical products and machinery. Just like it has been illustrated below in the Table 2, by 2001, 644 tariff lines were covered by the nontariff barriers, which is less than 0.1 of total tariff lines. Moreover, more than $30 \%$ of the last were subject to designated trading, which remained one of the less dangerous Chinese quantitative restrictions (Ianchovichina \& Martin, 2006).

Nevertheless, it is also fair to state that the aforementioned information regarding the non-tariff barriers might appear misleading due to a fact that there is a great number of variations once assessing the tariff lines and their significance. In order to achieve such significance of the non-tariff barriers, the current research offers the sophisticated calculations once considering the import coverage of the most crucial non-tariff barriers. The calculations used the respective data for the non-tariff barriers coverage with the corresponding import information according to the tariff line. In this regard, it should be stated that the scholars offer the following numbers. In addition, it should be stated that the data for 1992 was used in the calculations of 1996, while the trade data for 2000 was respectively used for 2001 (Ianchovichina \& Martin, 2006).

Table 2. Changes in the import coverage of nontariff barriers from 1996 to 2001 (Ianchovichina \& Martin, 2006)

\begin{tabular}{ccccccccc}
\hline & Licenses \& Quotas & Tendering & Licensing only & State Trading & Designated Trading & Any NTB & No NTBs & Total \\
\hline & $\%$ & $\%$ & $\%$ & $\%$ & $\%$ & $\%$ & $\%$ & $\%$ \\
$\mathbf{2 0 0 1}$ & 12.8 & 2.7 & 0.5 & 9.5 & 6.2 & 21.6 & 78.4 & 100 \\
$\mathbf{1 9 9 6}$ & 18.5 & 7.4 & 2.2 & 11.0 & 7.3 & 32.5 & 67.5 & 100 \\
\hline
\end{tabular}

Note. Calculations for 2001 performed by Mei Zhen of MOFTEC during an internship at the World Bank.

Thus, the import coverage of the Chinese non-tariff barriers has decreased considerably from 32.5\% in 1996 to $21.6 \%$ in 2001. Additionally, the import licensing coverage has decreased from $18.5 \%$ to $12.8 \%$ and the state trading coverage has fallen from $11 \%$ to $9.5 \%$ from 1996 to 2001 respectfully. Furthermore, the tendering requirements import coverage has decreased drastically, from $7.4 \%$ to $2.7 \%$, as well.

It is also necessary to state that the most important import item for China was oil and its products being the subjects to non-tariff barriers. Furthermore, they account for approximately $50 \%$ of the imports subject to any of the aforementioned non-tariff barriers. The second most significant category was the ferrous metals, which were also the subject to designated trading recommendations. In addition, imports of oil products constituted almost $84 \%$ of the import items subject to state trading (Ianchovichina \& Martin, 2006).

Traditionally, the average protective effect of the Chinese combination of the non-tariff regulation of their foreign trade was approximately assessed as $9.3 \%$ according to the World Bank data in the middle of 1990s. 
Moreover, the most effective way of protection of the Chinese domestic production came from the quota-constrained goods and licensing. Here it is also fair to state that the protective impact of the NTB (non-tariff barriers) has obviously decreased due to a simple fact that the assessment was conducted due to the progressive phase-out of the last with a corresponding standstill on the new non-tariff barriers introduction during the WTO accession procedure and along with an expected decline in their severity according to the recommendations of the WTO. However, for the Chinese agricultural sector, the scholars have also found out that some of the aforementioned measures have been implemented solely in a manner that could increase the positive levels of protection and reduce the negative ones. Moreover, the primitive rule of thumb that assumes the NTB protection to decrease with their coverage of the import would also assume that the NTB's protective effect has decreased to almost $5 \%$. The current project understands the considerably little margin of uncertainty connected with such measure and therefore it focuses only on the liberalization of the tariff in this regard, additionally assuming that the further results are to be considered as the lowest grade of the liberalization's impact (Ianchovichina \& Martin, 2006).

It is also worth mentioning that the Chinese tariff reform was escalated with a rapid speed, especially during the 1990 s, as the average tariffs were considerably high by the beginning of the 1990s, there was a considerable decline in 1994. In October 1996, there was an important tariff reform that reduced them dramatically, almost below 20\%. The further tariff reductions of 1999, 2000 and 2001 have reduced the tariffs even further; moreover, the reductions affected a considerable variety of items. The respective data on trends regarding the average tariff rates are provided below in the Table 3; in addition, the table analyzes the rates of the average tariffs after the accession of China to World Trade Organization. It is clearly visible that the progressive decreases of the tariffs in the period from 1992 to 2001 have also reduced the average tariffs by more than 60\%. However, it should also be stated that this has caused the considerable shortages in the manufacturing sector of the country, also ensuring that the further decreases of the tariffs recommended by the WTO's agreements would be significantly lower in percentage points. In addition, the substantial decrease of the tariff rates dispersion can also be considered one of the most crucial features of the tariff reforms. The reduction was from $32.1 \%$ in 1992 to $10 \%$ in 2001 (Ianchovichina \& Martin, 2006).

Table 3. Changes in average statutory tariff rates in China (\%) (Ianchovichina \& Martin, 2006).

\begin{tabular}{|c|c|c|c|c|c|c|}
\hline & \multicolumn{2}{|c|}{ All products } & \multicolumn{2}{|c|}{ Primary products } & \multicolumn{2}{|c|}{ Manufactures } \\
\hline & Simple & weighted & simple & weighted & simple & weighted \\
\hline 1992 & $42.9^{*}$ & 40.6 & 36.2 & 22.3 & 44.9 & 46.5 \\
\hline 1993 & 39.9 & 38.4 & 33.3 & 20.9 & 41.8 & 44.0 \\
\hline 1994 & 36.3 & 35.5 & 32.1 & 19.6 & 37.6 & 40.6 \\
\hline 1995 & 23.6 & 22.6 & 25.4 & 20.0 & 23.1 & 23.2 \\
\hline 1996 & 17.6 & 18.2 & 17.9 & 20.0 & 17.5 & 17.8 \\
\hline 1997 & 17.5 & 18.7 & 17.9 & 20.0 & 17.4 & 18.5 \\
\hline 1998 & 17.2 & 14.2 & 21.8 & 21.8 & 16.8 & 13.4 \\
\hline 1999 & 17.0 & 14.1 & 22.4 & 19.5 & 16.6 & 13.3 \\
\hline 2000 & 16.6 & 12.0 & 21.6 & 17.7 & 16.2 & 13.0 \\
\hline 2001 & 9.8 & 6.8 & 13.2 & 3.6 & 9.5 & 6.9 \\
\hline
\end{tabular}

* Source: World Bank (1999, p340) to Authors' calculations for tariff lines with imports from 1999 and China's final WTO offer. CDS Consulting Co. provided applied tariffs for 2001. Trade data come from COMTRADE.

Additionally, Table 4 illustrates the average tariffs that were applied during the 1995-2001 period with the tariffs after the WTO's recommendations that confined the tariffs during the end of the period of their implementation. There, the numbers suggest that China had a period of trade liberalization during they 1995-2001 years. The weighted average tariffs fell considerably for tobacco, beverages and wheat, light manufactures, apparel and textiles, metals, petrochemicals, electronics and automobiles. In addition, there was a study conducted by Huang and Rozelle that 
Table 4. Pre- and post-accession import protection (tariff or tariff equivalent) (Ianchovichina \& Martin, 2006)

\begin{tabular}{|c|c|c|c|c|c|c|}
\hline & \multicolumn{3}{|c|}{ China } & \multicolumn{3}{|c|}{ China Taipei } \\
\hline & 1995 & 2001 & Post-Accession & 1997 & 2001 & Post-Accession \\
\hline Rice & -5.0 & -3.3 & -3.3 & -2.2 & 0 & 0 \\
\hline Wheat & 25.0 & 12.0 & 12.0 & 6.5 & 6.5 & 6.5 \\
\hline Feed grains & 20.0 & 32.0 & 32.0 & 1.0 & 1.0 & 0 \\
\hline Vegetables \& fruits & -10.0 & -4.0 & -4.0 & 35.7 & 36.9 & 16.0 \\
\hline Oilseeds & 30.0 & 20.0 & 3.0 & 1.8 & 0.8 & 0.2 \\
\hline Sugar & 44.0 & 40.0 & 20.0 & 21.9 & 25.8 & 22.7 \\
\hline Plant fibers & 20.0 & 17.0 & 20.0 & 0 & 0 & 0 \\
\hline Livestock \& & -20.0 & -15.0 & -15.0 & 7.5 & 6.5 & 4.0 \\
\hline Dairy & 30.0 & 30.0 & 11.0 & 16.6 & 9.3 & 5.9 \\
\hline Processed food & 20.1 & 26.2 & 9.9 & 14.9 & 14.2 & 9.9 \\
\hline Beverages \& tobacco & 137.2 & 43.2 & 15.6 & 48.1 & 22.0 & 13 \\
\hline Extract & 3.4 & 1 & 0.6 & 5.5 & 5.5 & 4.1 \\
\hline Textiles & 56.0 & 21.6 & 8.9 & 6.1 & 6.3 & 5.6 \\
\hline Apparel & 76.1 & 23.7 & 14.9 & 12.8 & 13.4 & 11.2 \\
\hline Light manufactures & 32.3 & 12.3 & 8.4 & 4.0 & 4.1 & 3.4 \\
\hline Petrochemicals & 20.2 & 12.8 & 7.1 & 4.2 & 4.2 & 2.9 \\
\hline Metals & 17.4 & 8.9 & 5.7 & 4.0 & 3.8 & 1.5 \\
\hline Automobiles & 123.1 & 28.9 & 13.8 & 23.9 & 21.5 & 13.3 \\
\hline Electronic & 24.4 & 10.3 & 2.3 & 2.9 & 0.5 & 0.3 \\
\hline Other manufactures & 22.0 & 12.9 & 6.6 & 4.4 & 3.3 & 2.1 \\
\hline Trade \& transport & 1.9 & 1.9 & 0.9 & 1.3 & 1.3 & 0.7 \\
\hline Constriction & 13.7 & 13.7 & 6.8 & 5.9 & 5.9 & 2.9 \\
\hline Communications & 9.2 & 9.2 & 4.6 & 9.2 & 9.2 & 4.6 \\
\hline Commercial services & 29.4 & 29.4 & 14.7 & 3.7 & 3.7 & 1.9 \\
\hline Other services & 24.5 & 24.5 & 12.7 & 7.1 & 7.1 & 3.5 \\
\hline Total- Agriculture & 4.8 & 7.6 & 3.6 & 9.1 & 6.9 & 4.6 \\
\hline Total- Manufactures & 25.3 & 13.5 & 6.9 & 6.3 & 5.2 & 3.5 \\
\hline Total-Merchandise trade* & 24.3 & 13.3 & 6.8 & 6.5 & 5.2 & 3.6 \\
\hline
\end{tabular}

* The estimates in the table are based on trade weights for the respective years. If trade weights for 2000 at the six-digit level of the harmonized system are used the total weighted average tariffs in 2001 and 2007 are $12.2 \%$ and ${ }^{\wedge} .3 \%$, respectively, for China, and $4.5 \%$ and $3.1 \%$, respectively, for Chinese Taipei.

stated that particular agricultural items, like fruits and vegetables, meat, rice and livestock were subject to the 1995's negative protection. In addition, the increase of the protection of these items was also actual in the aforementioned period (Huang, Rozelle, \& Min, 2002). Moreover, the experts did not expect the protective measures on the majority of the agricultural items to fall down considerably after the China's accession to WTO; moreover, the protection of import was expected not to be changed for the majority of the items except dairy products, oilseeds and sugar (Ianchovichina \& Martin, 2006).

According to the studies, the protective measures were supposed to keep on falling for other merchandise items as well, particularly the reductions for beverages, processed food, electronics, automobiles and tobacco were expected by the specialists. For example, Francois states that the automobile sector's liberalization will be complemented by a colossal industry restructuring just to achieve an effective realization of the economies of scale and enhance the efficiency of the structure; in addition, he assumes that such measures will increase the productivity of the industry by $20 \%$ (Francois \& Spinanger, 2001).

As it has already been said above, China should have stopped subsidizing their exports after their accession to WTO. Huang and Rozelle also assume that for 2001 China subsidized 32\% of their exports of feed-grains and 10\% of their cotton and other plant-based fibers, as well. Certainly, the experts state that such measures will become history for China after the accession, as they are obliged never to subsidize their exports after signing the WTO agreements (Huang, Rozelle, \& Min, 2002).

Furthermore, China has had procedures complementing its policies of protecting their domestic production, including the domestic regulations and border measures, which have also reduced the effectiveness of their sectors of domestic service. Certainly, trade within the sectors was also affected negatively. Such measures being 
the trade barriers can also be fairly identified according to the terms of ad valorem. Moreover, the experts state that the most important effect of Chinese accession that reduces their trade barriers on $50 \%$.

Just like it has already been stated, the following section will discuss the Chinese policy of tax revenue replacement and its impact on the results of the accession of China to the World Trade Organization. The section will offer a comparison of the simulation, which assumes no replacement for the tariff revenue with the respective simulations where the lost revenue is being compensated by the increase of the output taxes. In addition, the results of the Chinese policy of tariff revenue replacement will be illustrated and summarized in the respective table (Walmsley, Hertel, \& Ianchovichina, 2006).

Such comparison provides an exhaustive and profound demonstration of the situation when the revenues from tariffs are being replaced by the household income taxes with the respective negative results for the Chinese economic system, as a result. Thus, the benefits from accession to WTO for China appear to be controversial rather than clear and evident. For example, Figure 2 illustrates the comparison of the differences of the cumulative percentages from the base case represented in GDP for both scenarios (Note 1) described previously. In this regard, despite the fact that within the period of 2003 and 2004 there was a significant increase in real GDP as a result from the improving efficiency of the economic system, the figure shows that the capital stocks were not able to accumulate equally to the similar level with the replacement of the tariff revenues; thus, it is fair to state that the real GDP of China would not increase significantly in future. In addition, this is being complemented by the fact that the capital itself increases slowly due to the accession with further replacement of the tax revenues; therefore, the curve of Chinese real GDP increases in 2003-2004 years and remains comparatively similar in further periods. According to the calculations, by 2020, the increase of real GDP would constitute for only $1.565 \%$, while the policy of lump sum replacement would show $4.25 \%$ increase in real GDP (Walmsley, Hertel, \& Ianchovichina, 2006).

The question why do the capital stocks are not able to accumulate with the replacement of tariff revenue as a result of China's accession to WTO appears simple to discuss. Firstly, it should be stated that the capital accumulation itself is the result of the return's high rates being continuously driven to equality in due time. In the situation when the revenue is not being replaced, the return rates tend to increase substantially due to the fact that the capital's rental price increases according to the capital goods' price. This trend can also simply be explained by the fact that the capital's rental price increases with the increasing demand for the internal production; in addition, the lower expenditures on the inputs that were imported resulted in the decreasing price for the capital goods. On the contrary, with the replacement of the tariff revenue by the increasing taxes on the household income results in the reduction of the extent of increase of capital's rental price. Thus, it becomes evident why do the return on capital rates not able to increase respectively. This situation is being explicitly illustrated by the Figure 3, where there is no significant increase in rates of return of Chinese economic system with the accession, especially once compared to the situation when there is no replacement (Walmsley, Hertel, \& Ianchovichina, 2006).
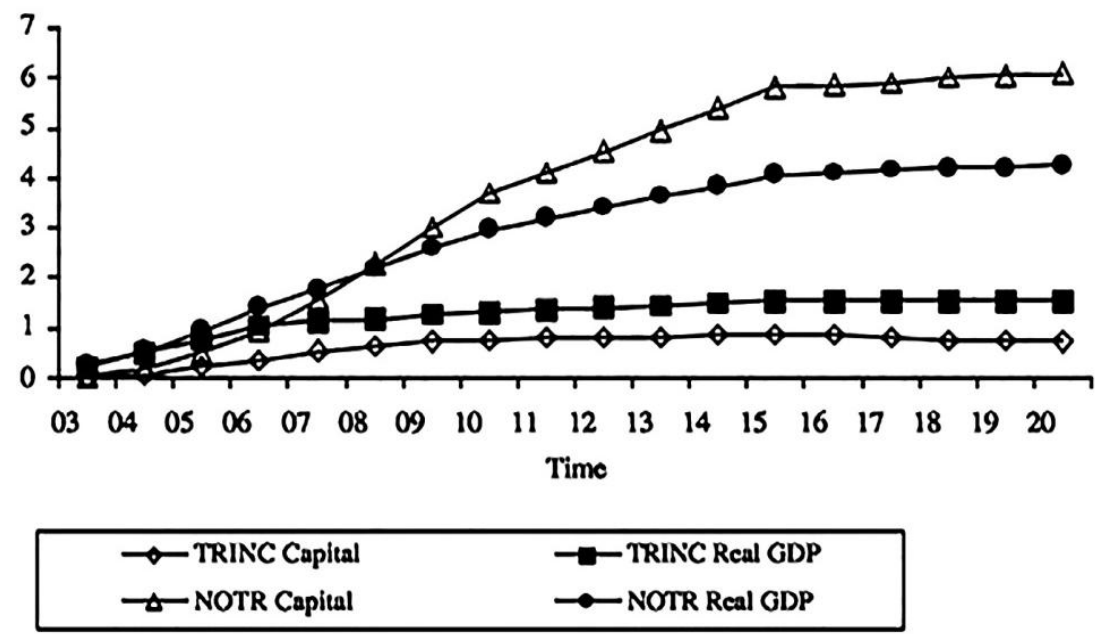

Figure 2. Cumulative percentage differences in China's real GDP and capital stocks: comparison of lump-sum and tax revenue replacements (Walmsley, Hertel, \& Ianchovichina, 2006) 


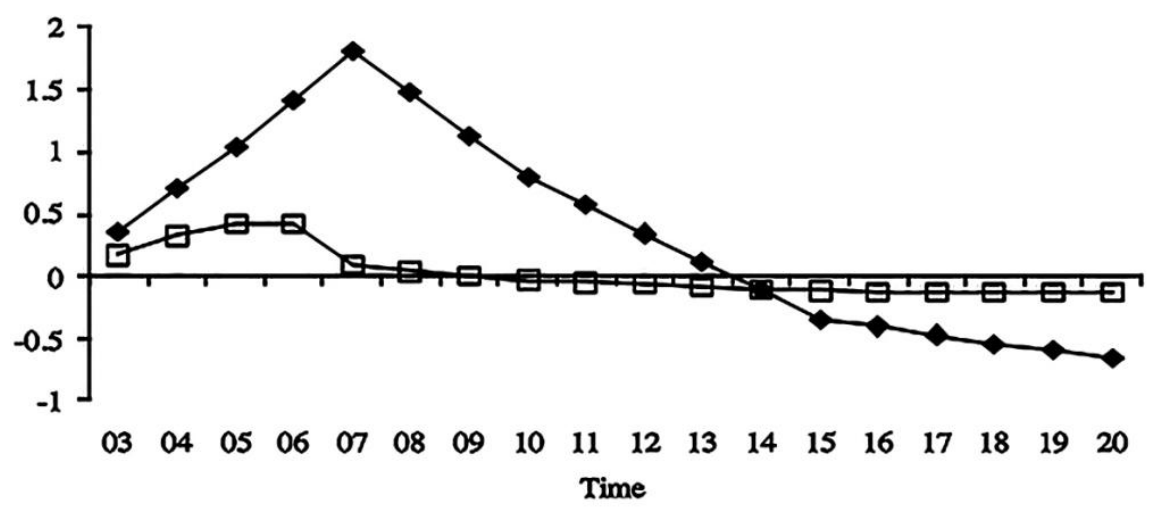

—NOTR モ-TRUNC

Figure 3. Cumulative percentage differences in China's rates of return: comparison of lump-sum and tax revenue replacement (Walmsley, Hertel, \& Ianchovichina, 2006)

In addition, the changes of the percentages in the rate of return is also being subdivided into the respective changes in the prices of capital goods and the rental price according to the Figures 4 and 5. The last show that any change of the return rate within the tax revenue replacement policy can be explained with the decline in the capital's rental prices. Still such difference fails to explain comprehensively the decline in the rate of return being actual for the tax revenue replacement policy even despite the fact that the changes of the capital goods' prices are different among both scenarios. However, the fact is that the decline of the prices of capital goods under the tariff revenue replacement policy is comparatively bigger compared to the scenario of lump-sum replacement. Such decline would result in an offset of the decrease of the capital's rental price, also causing slight increase of the return rate. Although, the last would not increase to an extent that it could cause the substantial increase of the return rate. In total, the household income taxes being increased as the reimbursement for the lost revenues from tariffs would potentially reduce any stimulus for the investors to transfer their financial resources into the Chinese markets (Walmsley, Hertel, \& Ianchovichina, n.d.).

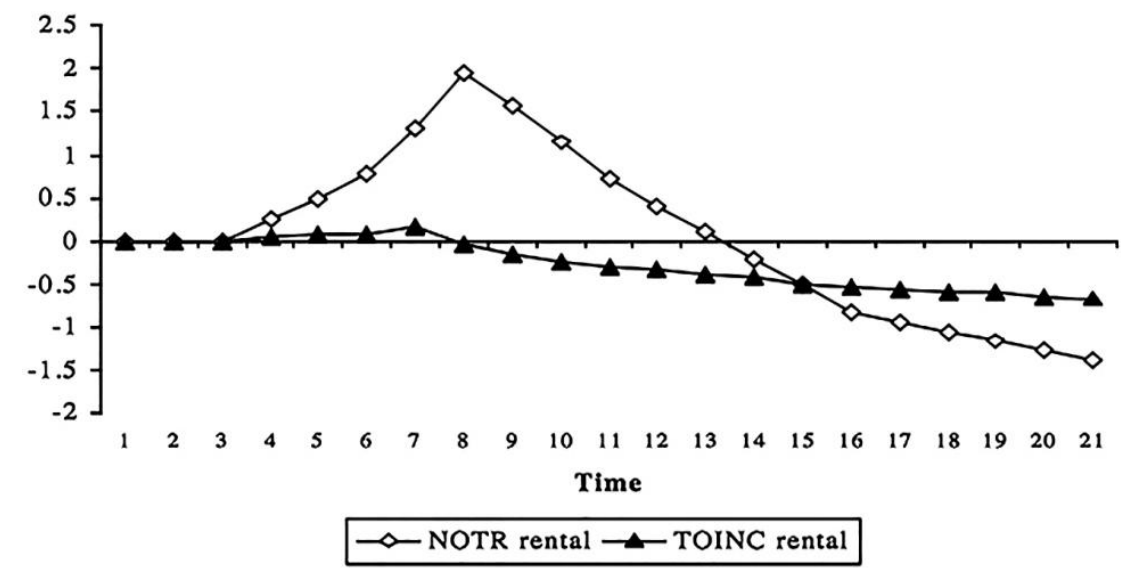

Figure 4. Cumulative percentage differences in China's rental price of capital: comparison of lump-sum and tax revenue replacement (Walmsley, Hertel, \& Ianchovichina, 2006) 


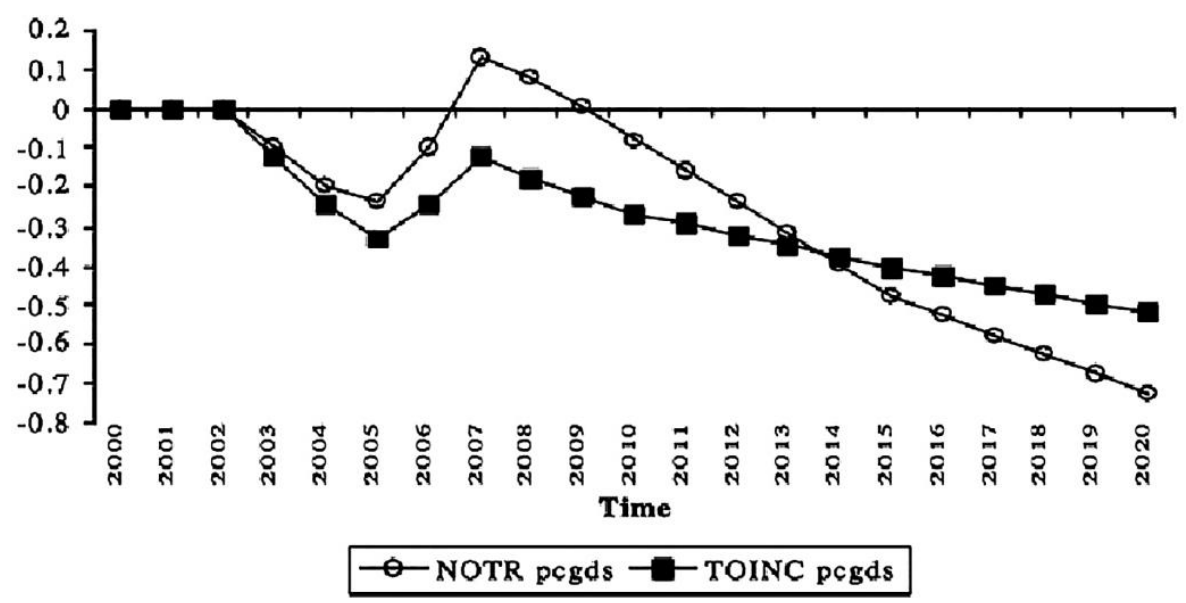

Figure 5. Cumulative percentage differences in China's price of capital goods: comparison of lump-sum and tax revenue replacement (Walmsley, Hertel, \& Ianchovichina, 2006)

As the Chinese small rates of return and poor capital accumulation give no stimulus for the foreign investors to work with China, the amounts of FDI's increase will be small just like it is illustrated in the Figure 6. Such policy of the replacement of tariff revenue has negatively balanced the positive achievements gained from the accession to WTO; therefore, the foreign investors rarely choose Chinese enterprises for their investments (Walmsley, Hertel, \& Ianchovichina, n.d.).

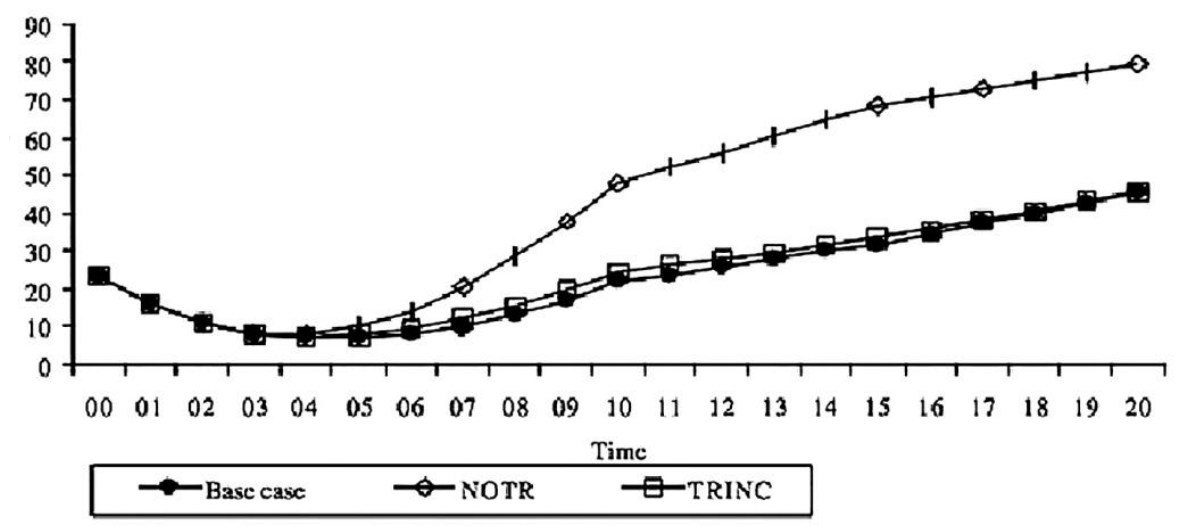

Figure 6. Foreign ownership of chinese assets: comparison of lump-sum and tax revenue replacement (Walmsley, Hertel, \& Ianchovichina, 2006)

Such results are not obviously much promising for the Chinese government, as they seek to retain their current revenue rates. It should be also noticed that the consequences of the implementation of the tax revenue replacement policy, especially on the investment attractiveness of China, should be handled by the government as soon as possible with the respective radical measures. The current section describes the income taxes as the part of the Chinese taxation system, which is still being developed and adjusted; nevertheless, it is recommended for the government of China to consider another policy of tariff revenue replacement, as there is a number of less distortionary replacement systems, for example, the losses of tariff revenues could have been reimbursed with the help of the consumption tax.

In this regard, Tables 5 and 6 of the research illustrate the consequences of the Chinese accession to the World Trade Organization with a replacement of tax revenue and a lump-sum replacement. The fact is that the welfare of the households in China is being reduced significantly due to the fact that the tariff revenue losses are compensated with their current replacement policy (Walmsley, Hertel, \& Ianchovichina, n.d.). 
Table 4. China's accession with lump-sum replacement (Walmsley, Hertel, \& Ianchovichina, 2006)

\begin{tabular}{ccccccccccc}
\hline & I & II & III & IV & V & VI & VII & VIII & XI & X \\
\hline & Real & Capital & $\begin{array}{c}\text { Real } \\
\text { GDP }\end{array}$ & $\begin{array}{c}\text { Real } \\
\text { stocks }\end{array}$ & $\begin{array}{c}\text { Actual } \\
\text { Export } \\
\text { Import }\end{array}$ & $\begin{array}{c}\text { Rate of } \\
\text { Wealth of regional } \\
\text { household in } \\
\text { Romestic Assets }\end{array}$ & $\begin{array}{c}\text { Wealth of regional } \\
\text { household in } \\
\text { Foreign Assets }\end{array}$ & $\begin{array}{c}\text { Foreign wealth } \\
\text { located in } \\
\text { regional firms }\end{array}$ & $\begin{array}{c}\text { Total wealth } \\
\text { of regional } \\
\text { Households }\end{array}$ & Welfare \\
\hline NAmerica & -0.086 & -0.334 & 0.945 & 1.911 & 0.135 & -0.040 & 1.404 & -1.63 & 0.093 & 7630.672 \\
WEurope & -0.070 & -0.323 & -0.037 & 0.227 & 0.203 & -0.003 & 0.374 & -0.43 & 0.141 & 3806.634 \\
Japan & -0.135 & -0.309 & 0.780 & 0.987 & 0.165 & 0.054 & 0.764 & -0.83 & 0.295 & 1621.029 \\
China & 4.256 & -6.078 & 17.592 & 16.717 & -0.657 & 5.232 & -13.446 & 23.11 & 0.749 & 10522.7 \\
Taiwan & 3.373 & 8.529 & 12.925 & 14.240 & -0.814 & 8.170 & -5.945 & 22.66 & 2.437 & 6363.929 \\
OthNICs & 0.125 & 0.245 & 0.480 & 0.591 & 0.073 & 0.489 & -0.388 & 1.22 & 0.393 & 1028.603 \\
SEA & -0.597 & -0.921 & -0.818 & -0.784 & 0.138 & -0.673 & 1.558 & -3.08 & 0.017 & -1608.04 \\
SoAsia & -0.819 & -1.921 & -3.284 & -3.467 & 0.359 & -1.234 & 7.717 & -9.27 & -1.209 & -2515.28 \\
LatinAM & -0.205 & -0.410 & -0.597 & -0.241 & 0.111 & 0.082 & 1.443 & -1.18 & 0.089 & -418.299 \\
AfrMide & -0.237 & -0.476 & -0.631 & -0.432 & 0.181 & 0.027 & 1.084 & -0.99 & 0.051 & -764.427 \\
ROW & -0.131 & -0.339 & -0.110 & 0.070 & 0.161 & 0.144 & 0.889 & -0.59 & 0.156 & -0.12169 \\
\hline
\end{tabular}

Table 5. China's accession with tax revenue replacement (Walmsley, Hertel, \& Ianchovichina, 2006)

\begin{tabular}{|c|c|c|c|c|c|c|c|c|c|c|}
\hline & I & II & III & IV & V & VI & VII & VIII & XI & $\mathbf{X}$ \\
\hline & $\begin{array}{l}\text { Real } \\
\text { GDP }\end{array}$ & $\begin{array}{l}\text { Capital } \\
\text { Stocks }\end{array}$ & $\begin{array}{c}\text { Real } \\
\text { Export }\end{array}$ & $\begin{array}{c}\text { Real } \\
\text { Import }\end{array}$ & $\begin{array}{l}\text { Actual } \\
\text { Rate of } \\
\text { Return }\end{array}$ & $\begin{array}{l}\text { Wealth of regional } \\
\text { household in } \\
\text { Domestic Assets }\end{array}$ & $\begin{array}{c}\text { Wealth of regional } \\
\text { household in } \\
\text { Foreign Assets }\end{array}$ & $\begin{array}{c}\text { Foreign wealth } \\
\text { located in } \\
\text { regional firms }\end{array}$ & $\begin{array}{c}\text { Total wealth of } \\
\text { regional } \\
\text { Households }\end{array}$ & Welfare \\
\hline NAmerica & -0.006 & -0.108 & 1.083 & 1.837 & 0.022 & -0.018 & 0.502 & -0.53 & 0.025 & 8151 \\
\hline WEurope & 0.023 & -0.007 & 0.069 & 0.236 & 0.016 & 0.041 & 0.053 & 0.03 & 0.045 & 4359.5 \\
\hline Japan & 0.012 & 0.027 & 0.930 & 0.866 & 0.006 & 0.254 & 0.094 & 0.42 & 0.212 & 847.25 \\
\hline China & 1.565 & 0.724 & 13.734 & 13.407 & -0.142 & 0.201 & -0.381 & 0.79 & 0.030 & 3909.25 \\
\hline Taiwan & 3.371 & 8.519 & 12.757 & 13.948 & -0.887 & 8.055 & -4.826 & 22.68 & 2.277 & 1036.875 \\
\hline OthNICs & 0.232 & 0.467 & 0.478 & 0.560 & -0.036 & 0.523 & -1.313 & 2.39 & 0.281 & 6852.719 \\
\hline SEA & -0.380 & -0.567 & -0.559 & -0.498 & 0.067 & -0.421 & 0.885 & -1.71 & -0.055 & 1036.875 \\
\hline SoAsia & -0.726 & -1.728 & -3.133 & -3.319 & 0.250 & -1252 & 6.130 & -8.12 & -1.231 & -1366.81 \\
\hline LatinAM & -0.107 & -0.209 & -0.466 & -0.290 & 0.028 & -0.024 & 0.600 & -0.65 & -0.021 & -2493.19 \\
\hline AfrMide & -0.086 & -0.164 & -0.513 & -0.360 & 0.032 & -0.037 & 0.302 & -0.37 & -0.029 & -324.875 \\
\hline ROW & -0.030 & -0.063 & -0.156 & -0.051 & 0.023 & 0.039 & 0.164 & $-0 / 09$ & 0.041 & -72.3125 \\
\hline
\end{tabular}

As for the more contemporary state of the tariff revenues of China after the WTO's accession, it should be mentioned that the government of China continuously reduces its import duties; in particular, for the products of highly confined by the taxes. For example, the variety of import goods are now being easier to purchase for the consumers, from cosmetics to shoes. Such measure obviously boosts the consumption of these products on the domestic markets, especially for the population of China that used to shop abroad due to the high costs of the imported goods (Burkitt, 2015).

On May 2015, the Ministry of Finance stated that it would reduce the import tariffs by almost half on the items including but not limited to shoes, fur garments and suits till the beginning of June. They also stated that the tariff for cosmetics would be reduced from $5 \%$ to $2 \%$ and the tariff for diapers would be reduced from 7,5\% to $2 \%$. Due to such boost of the spending within the economic system of China the growth of the retail sales appears more than evident; however, such measure also resulted in the worst performance of the Chinese economic system for the last six years. The economy has grown only to 7\%, the worst dynamic when compared to the previous years. Such slowdown also has provoked the sharp criticism from the policy makers that had previously suggested that such measure would injure the tax revenues (Burkitt, 2015).

However, the governmental structures still state that such measure was intended to stimulate the Chinese consumers to spend their money within the inner borders of the country. Moreover, such measure is also focused on the expenditures of the tourists visiting the Chinese cities and territories, as the last would definitely purchase low-cost imported goods rather than doing the same at home; moreover, they would not have to pay any added values for these goods. The analytics state that the Chinese tariffs are able to potentially make the imported goods more expensive for approximately $20 \%$, which appears to be considerably less once comparing to the 
prices of the foreign markets (Burkitt, 2015).

Moreover, due to another fact, the continuous strengthening of Yuan against the Euro, US Dollar and other currencies, it is also clearly visible why did the shopping within the Chinese borders become more appealing for the inside and outside consumers. As a result, the tourists visiting China spent approximately $\$ 165$ billion in 2014, which is bigger than the same of 2013, as the State Administration of Foreign Exchange states.

In addition, the experts state that such tariff reductions are a great advantage for the transnational corporations. For example, Linda Li, a Mintel Group Ltd. senior research analyst states that "this would be good news for international players in China, as the lower tariff would entitle the imported products to apply relatively more competitive prices in China than before." (Burkitt, 2015).

Also stated that approximately $90 \%$ of the consumers of China going abroad in the previous year bought cosmetics, $85 \%$ of them-footwear and clothes; in addition there were $64 \%$ of them who purchased the baby-care products. Nevertheless, the official response from the transnational corporations remains unclear due to the fact that the majority of them did not express any eagerness to estimate the changes associated with this event and the last are still preparing the calculations in order to provide a clear estimation of the results. Nevertheless, the analytics state that this measure will return their customers at home. In this regard, the HSMC's head of consumer and retail research, Erwan Rambourg stated that "it is understandable that instead of losing business to Galeries Lafayette in Paris, Harrods in London, or shopping malls in Hong Kong, China's administration may want to tap into the power of domestic consumption". (Burkitt, 2015).

Although, this tariff reductions appears more negative for Hong Kong, where there has always been a tax-free market for all the Chinese consumers. Rambourg also stated that Hong Kong had been already injured by this move, due to a simple fact that the consumers have visited the foreign markets. In addition, there were another factors that resulted in the decreased consumption rates in Hong Kong; for example, the strength of US. Dollar, the political protests in the city, local indignation against the enormous crowds of the shoppers etc. (Burkitt, 2015).

Nevertheless, there is still a clam that the Chinese government needs to reduce their tariffs even further to compete with the foreign markets. Ben Cavender, an analyst from China Market Research states exactly the same, otherwise, he assumes that the Chinese consumers would still rather turn to the foreign markets in search for the cheap foreign goods (Burkitt, 2015).

\section{Conclusions}

Therefore, summarizing everything that has been mentioned above, it should be stated that the Chinese accession to WTO has become the logical move towards the development of the economic system of the country, especially in the aspects of its foreign trade. For example, its is evident that WTO has dramatically liberalized the foreign trade policy of China, giving the importers the best opportunities to work on the Chinese markets and to purchase the imported goods for a cheaper price for the Chinese consumers. However, it should also be stated that obviously the amounts of the tax and customs revenues of China after accession had reduced dramatically, therefore, the financial institutions of China had had to design a way to compensate the losses. The project has offered an analysis of such compensation strategies and stated that they appeared to be not that effective that they had been introduced to the public. In addition, the paper offered another effective way to compensate the losses of the tariff revenues, as well.

It should also be reminded that China has made a considerable breakthrough in reducing the nontariff barriers coverage, abolishing the foreign trade confines and reducing tariffs, as well. This substantial progress can be dated within the period of 1990s when they have nullified the exchange rate regime trade distortions.

by 2001, 644 tariff lines were covered by the nontariff barriers, which is less than 0.1 of total tariff lines. Moreover, more than $30 \%$ of the last were subject to designated trading, which remained one of the less dangerous Chinese quantitative restrictions.

However, the fact is that the decline of the prices of capital goods under the tariff revenue replacement policy is comparatively bigger compared to the scenario of lump-sum replacement. Such decline would result in an offset of the decrease of the capital's rental price, also causing slight increase of the return rate. Although, the last would not increase to an extent that it could cause the substantial increase of the return rate. In total, the household income taxes being increased as the reimbursement for the lost revenues from tariffs would potentially reduce any stimulus for the investors to transfer their financial resources into the Chinese markets

Nevertheless, it should also be stated that this was not only the Chinese agreements with WTO that completely reshaped the Chinese tariffs on imports and their export-stimulating policies. It was a historical process of 
continuous and gradual liberalization of the Chinese economy, starting from the first years of the Chinese foreign trade. Therefore, such losses of the tariff revenues are obviously understood by the government and the financial institutions; however, the decreasing rates of the import tariffs make their native consumers spending within the Chinese borders. Such move can also be considered as the positive way of the compensation of such losses. Thus, it is fair to state that China is still experimenting on the ways to compensate the losses of the tariff revenues; however, it is still being challenging for the Chinese government, nonetheless.

\section{References}

Burkitt, L. (2015). China to Cut Taxes on Some Imported Consumer Goods to Spur Spending. Retrieved from http://www.wsj.com/articles/china-to-cut-tariffs-on-some-imported-consumer-goods-to-spur-spending-1432 538808

Cctv.com. (2015). Customs Chief on Tariff Revenue after WTO Entry. Retrieved Aug. 19, 2015 from http://www.cctv.com/special/180/1/23002.html

Data.worldbank.org. (2015). Tariff rate, applied, weighted mean, all products. Retrieved Aug. 21, 2015 from http://data.worldbank.org/indicator/TM.TAX.MRCH.WM.AR.ZS

Fanchang, K. (1996). Survey on China's Tariff and Non-tariff Barriers. Beijing:12.: APEC Policy Research Center (APRC).

Francois, J., \& Spinanger, D. (2001). Greater China's Accession to the WTO: Implications for International Trade/Production and for Hong Kong. Retrieved Aug. 21, 2015 from https://www.gtap.agecon.purdue.edu/resources/res_display.asp?RecordID=1077

Hong, C. (2013). The political economy of tariff protection in China: Evidence from the WTO accession. Canadian Journal of Economics/Revue Canadienne D'ÉConomique, 46(4), 1295-1316. http://dx.doi.org/10.1111/caje.12049

Huang, J., Rozelle, S., \& Min, C. (2002). The Nature of Distortions to Agricultural Incentives in China and Implications of WTO Accession. Beijing. http://dx.doi.org/10.2139/ssrn.331781

Ianchovichina, E. (2004). Impacts of China's Accession to the World Trade Organization. The World Bank Economic Review, 18(1), 3-27. http://dx.doi.org/10.1093/wber/lhh030

Ianchovichina, E., \& Martin, W. (2001). Trade Liberalization in China's Accession to WTO. Journal of Economic Integration, 16(4), 421-446. http://dx.doi.org/10.11130/jei.2001.16.4.421

Ianchovichina, E., \& Martin, W. (2006). Trade Impacts of China's World Trade Organization Accession. Asian Econ Policy Rev, 1(1), 45-65. http://dx.doi.org/10.1111/j.1748-3131.2006.00005.x

Kim, C. (1997). Issues in the negotiations on China's accession to the WTO system, remarks.

Rihui, C. (1996). On China's Entry into WTO. Development Study.

State Statistical Bureau. (1997). Statistical Yearbook of China. Beijing: China Statistical Publishing House.

Stats.gov.cn. (2015). China Statistical Yearbook-2014. Retrieved Aug. 21, 2015 from http://www.stats.gov.cn/tjsj/ndsj/2014/indexeh.htm

The Economist. (2011). All change. Retrieved Aug. 19, 2015 from http://www.economist.com/node/21541448

Walmsley, L., Hertel, T., \& Ianchovichina, E. (2006). Assessing the Impact of China's WTO Accession on $\begin{array}{lllll}\text { Foreign } & \text { Ownership. } & \text { Retrieved } & \text { Aug. } & \end{array}$ https://www.gtap.agecon.purdue.edu/resources/download/312.pdf

World Bank. (2002). China: Country Economic Memorandum.

World Trade Organization. (2011). China in the WTO: Past, Present and Future. Retrieved Aug. 21, 2015 from https://www.wto.org/english/thewto_e/acc_e/s7lu_e.pdf

WTO.org. (2015). WTO|China - Member information. Retrieved Aug. 21, 2015 from https://www.wto.org/english/thewto_e/countries_e/china_e.htm

Yijnling, Z. (n.d.). Liberalisation of the Chinese Economy: APEC, WTO and Tariff Reductions. http://dx.doi.org/10.2307/3182330 


\section{Note}

Note 1 . The policy simulations are:

A. NOTR: The first policy scenario involves examining the effect of China's accession on foreign investment using the Dynamic GTAP model adjusted for duty drawbacks. It is also assumed that tariff revenue, lost from the reduction in tariffs, is not replaced by increases in other taxes, nut instead there is simply a lump-sum transfer from households to the Government. This scenario is referred to as NOTR.

B. TRINC: In this scenario lost tariff revenues is replaced with a tax on household incomes. These taxes respond endogenously in order to cover any lost tariff revenue. The household income taxes on all factors adjust by the same percentage to ensure that the ratio of tax revenue to income remains unchanged. This scenario is referred to as TRINC.

\section{Copyrights}

Copyright for this article is retained by the author(s), with first publication rights granted to the journal.

This is an open-access article distributed under the terms and conditions of the Creative Commons Attribution license (http://creativecommons.org/licenses/by/3.0/). 